\title{
Treatment of active chronic hepatitis with cyclophosphamide
}

\author{
R. NACCARATO \\ M.D. \\ M. Chiaramonte \\ M.D.
}

\author{
R. FARINI \\ M.D. \\ U. FAGIOLO \\ M.D. \\ G. C. Sturniolo
M.D.
}

Instituto di Patologia Speciale Medica e Metodologia Clinica dell'Universita' di Padova

Summary

Twenty patients with active chronic hepatitis, classified on the basis of the treatment into three groups, have been studied: (1) patients treated with cyclophosphamide (10 patients); (2) patients treated with cyclophosphamide after cycles of corticosteroid therapy (four patients); (3) patients treated with corticosteroid (six patients).

In all patients we observed clinical, biochemical and immunological changes during and after treatment.

Hepatic needle-biopsy was performed in all patients before treatment. The histological picture was rechecked after the first cycle of therapy in twelve patients.

The results obtained in the three groups of patients have been statistically compared.

Cyclophosphamide treatment produces an improvement of general conditions and a persistent normalization of several biochemical and immunological data, especially in those patients in which active chronic hepatitis was not in an advanced stage (type $A$ aggressive form). The histological picture showed no changes after treatment.

\section{Introduction}

Numerous immunological and histological data have given rise to the assumption that active chronic hepatitis (ACH) is closely related to autoimmune phenomena (MacKay, Taft and Cowling, 1956; Popper, Paronetto and Schaffner, 1965; MacKay, Weiden and Hasker, 1965). Nevertheless, it is not known if these immunological changes are the cause or the effect of the disease.

Some cases of ACH seem strictly related to previous acute viral hepatitis, mainly hepatitisassociated antigen (HAA) positive (Sutnick, London and Blumberg, 1971; Naccarato et al., 1972). It is still uncertain whether or not the persistence of a virus in the organism, and above all in the liver, can

Correspondence: Dr Remo Naccarato, M.D., xxv, Istituto Patologia Medica, Policlinico Universitario, 35100 Padova, ltalia. imply pathogenetic importance in the development of the disease.

The problem of the treatment of $\mathrm{ACH}$ remains unsolved at the present time.

In the last years, in relation to the autoimmunological assumptions in the pathogenesis of the disease, the use of immunosuppressant drugs was emphasized. The results obtained are still incomplete and fragmentary.

The most widely used immunosuppressant drugs are the steroid derivatives. This treatment, applied during the early active phase of $\mathrm{ACH}(2-3$ years\$ $\vec{\theta}$ reduces the mortality rate and produces in improve $I$ ment in the general condition of the patients treate $\overline{6}$. Corticosteroid treatment has also a significant effect in raising serum albumin and in reducing total serum globulins (MacKay and Wood, 1962; Cook, Mulligan and Sherlock, 1971).

Other immunosuppressant drugs, such as 6mercaptopurin and azathioprine, sometimes in association with corticosteroids, are used, but the efficiency of these therapies is still under discussion. The results obtained were often contradictory. However, some authors observed an improvement in the clinical and biochemical pictures, mainly in moderate $\mathrm{ACH}$, using combined prednisone-azathioprine therapy (MacKay, Weiden and Ungar, 1964; Solway et al., 1970; Mistilis and Blackburn, 1967).

The mechanism of action of immunosuppressive agents is not completely known. They seem to suppress the proliferation of the immunoactive lymphocytes and to have possible anti-viral effects (Page, Condie and Good, 1964).

Treatment may be followed by some side-effects (leucopoenia, thrombopoenia, gastric intolerance, infections), and these drugs can have an hepatotoxic action (Kravit et al., 1967; Mistilis and Blackburn, 1967).

Although the importance of the immunological $\stackrel{\mathbb{Q}}{\rightarrow}$ phenomena in the pathogensis of $\mathrm{ACH}$ is not fully explained at present, we maintain that immunosuppressant treatment must be undertaken in the active stage of this disease. 
Cyclophosphamide (Cy), an alkilating agent, used for long periods of time in several diseases (cancer chemotherapy, especially Hodgkin's disease and other malignant reticuloses), can suppress a variety of immunological phenomenon in experiments with animals and in observations on human beings (Santos, 1967; Nakamura and Weigle, 1970; Steinberg et al. 1971; Paterson, Drobish and Biddick, 1971; Alepa, Zvaifler and Sliwinski, 1970; Booth and Able, 1970; Grushkin et al., 1970).

The hepatotoxic action of this drug is doubtful. It is present in neither the experimental nor in the clinical use (Grushkin et al., 1970; Lavin and Koss, 1971).

The immunological suppressive action of $\mathrm{Cy}$ is not entirely related to the cytotoxic action, like 6-mercaptopurin and azathioprine (Santos, 1967; Nakamura and Weigle, 1970; Alepa et al., 1970; Grushkin et al., 1970; Paterson, Drobish and Biddick, 1971).

Long-term treatment with this drug has no devastating side-effects although cases of sterility after $\mathrm{Cy}$ treatment have recently been reported (Fairley, Barrie and Johnson, 1972).

Biological effects of $\mathrm{Cy}$ require its microsomial oxidation and its conversion into at least two cytostatic alkilating agents, one of which is nitrogen mustard. This phenomenon appears to take place in the liver (Brock and Hohorst, 1963).

For all these reasons we decided to use this drug in the treatment of the active stage of $\mathrm{ACH}$. This therapy was carried out discontinuously, as is the normal procedure.

We treated with Cy one group of patients who had no previous immunosuppressant therapy and a second smaller group who had had previous corticosteroid treatment. The results obtained in these two groups of patients were compared first with each other and then with results obtained from a third group treated with corticosteroid therapy alone.

All the patients showed immunological and histological findings indicating that the disease was active (increase of serum immunoglobulins, presence in the blood of anti-smooth muscle and antiglomerular basal membrane antibodies; lymphomononuclear infiltration of the portal bile tracts and along the liver cells, piecemeal necrosis of the liver cells).

Immunosuppressant therapy was not used in the absence of these findings.

We did not leave any patients without treatment for use as controls as the mortality rate is higher and the general condition worse in those patients with ACH without any therapy (Cook et al., 1971).

This study has been performed with the purpose of verifying the efficiency of the cyclophosphamide treatment in active chronic hepatitis.
Patients and therapeutic outlines

We have studied twenty patients with $\mathrm{ACH}$, classified on the basis of the treatment into three groups:

Group 1. Patients treated with cyclophosphamide (Cy) (ten patients).

The outline of the therapy in these patients was: (a) $200 \mathrm{mg}$ daily i.v. up to a total of 5-6 g; (b) suspension of the treatment for 1-3 months; (c) 100-150 mg daily orally or i.v. up to a total of 4-5 g; (d) suspension of the treatment for 1-3 months; (e) possible resumption of the therapy with $100-150 \mathrm{mg}$ daily orally or i.v. up to a total of 4-5 g.

The therapy was applied with weekly check-ups (or more frequently, if necessary) of WBC, RBC, platelets. This therapy was changed or stopped if and whenever leucopoenia, thrombopoenia or other important side-effects appeared. These patients were clinically checked for 6-18 months.

Group 2. Patients treated with $\mathrm{Cy}$ after cycles of corticosteroid therapy (Cy after St) (four patients).

These patients were treated, 3-24 months before the beginning of $\mathrm{Cy}$ treatment, with courses of corticosteroid therapy (15-20 mg prednisolone daily in courses of 2-3 months). The subsequent treatment with $\mathrm{Cy}$ was applied according to the above mentioned outline. These patients were clinically checked for 5-16 months.

Group 3. Patients treated with corticosteroid therapy (St) (six patients).

These patients, checked for 8-24 months, were treated with cycles of corticosteroid therapy (15-20 $\mathrm{mg}$ of prednisolone or 16-24 mg daily of triamcinolone in cycles of 2-3 months).

All the patients of the three groups were admitted to the hospital for 45-60 days. Afterwards, we prescribed rest and a quiet life, possibly at home, in addition to the therapy.

The diagnosis of ACH was established on the basis of clinical, biochemical, immunological and histological data (Tables 1 and 2).

\section{Methods}

In all the patients the development of the clinical, biochemical and immunological picture was recorded during and after the treatment. Data after the beginning of therapy was recorded at intervals of $1,2,4,7-9,10-12,13-15,16-18$ and 24 months.

Hepatic needle-biopsy was performed in all the patients before the treatment. The histological picture was re-checked after the first cycle of the therapy in twelve patients. The histology was appraised in accordance with the criteria for classification established by De Groote et al. (1968).

The clinical data studied were: asthenia, dyspepsia, arthromyalgias, alteration of bowel movements and of diuresis. In examination we looked for the 
TABLE 1. Clinical and histological data of twenty patients with active chronic hepatitis $(\mathrm{ACH})$ treated with cyclophosphamide $(\mathrm{Cy})$, with cyclophosphamide after steroid therapy (Cy after St), and with steroids (St)

\begin{tabular}{|c|c|c|c|}
\hline & $\begin{array}{c}\mathrm{Cy} \\
\text { ten patients }\end{array}$ & $\begin{array}{c}\text { Cy after St } \\
\text { four patients }\end{array}$ & $\begin{array}{l}\text { St } \\
\text { six patients }\end{array}$ \\
\hline \multicolumn{4}{|l|}{ Clinical data } \\
\hline Sex: males & 2 & 2 & 4 \\
\hline females & 8 & 2 & 2 \\
\hline Age: $<30$ years & 4 & 2 & 3 \\
\hline$>30$ years & 6 & 2 & 3 \\
\hline Appearance of the disease: evident & 3 & 2 & 3 \\
\hline insidious & 7 & 2 & 3 \\
\hline \multicolumn{4}{|l|}{ Date of appearence of illness: } \\
\hline$<1$ year & 3 & 2 & 4 \\
\hline$>1$ year & 7 & 2 & 2 \\
\hline History: hepatitis & 3 & 2 & 3 \\
\hline alcohol & 5 & 3 & 3 \\
\hline $\begin{array}{l}\text { other (drugs, biliary tract } \\
\text { infectious, etc.) }\end{array}$ & 3 & 1 & 1 \\
\hline Associated illnesses & 4 & 2 & 4 \\
\hline Malaise, nausea & 10 & 3 & 5 \\
\hline Jaundice & 5 & 3 & 3 \\
\hline Hepatomegaly & 10 & 4 & 6 \\
\hline Splenomegaly & 4 & 2 & 6 \\
\hline Oedema, ascitis & 2 & 2 & 3 \\
\hline \multicolumn{4}{|l|}{ Histological data } \\
\hline Chronic aggressive hepatitis type $\mathrm{A}$ & 8 & 一 & 3 \\
\hline Chronic aggressive hepatitis type $B$ & 2 & 4 & 3 \\
\hline with cirrhosis & 2 & 2 & 1 \\
\hline without cirrhosis & - & 2 & 2 \\
\hline
\end{tabular}

TABLE 2. Humoral and immunological data of twenty patients with $\mathrm{ACH}$

\begin{tabular}{|c|c|c|c|}
\hline & $\begin{array}{c}\mathrm{Cy} \\
\text { ten patients }\end{array}$ & $\begin{array}{c}\text { Cy after St } \\
\text { four patients }\end{array}$ & $\begin{array}{c}\text { St } \\
\text { six patients }\end{array}$ \\
\hline \multicolumn{4}{|l|}{ Humoral data: } \\
\hline Serum bilirubin $>1 \mathrm{mg} \% \mathrm{ml}$ & 8 & 2 & 4 \\
\hline $\mathrm{S}-\mathrm{GOT}>40 \mathrm{UW} / \mathrm{ml}$ & 6 & 3 & 6 \\
\hline $\mathrm{S}-\mathrm{GPT}>40 \mathrm{UW} / \mathrm{ml}$ & 6 & 3 & 6 \\
\hline $\mathrm{S}-\mathrm{OCT}>100 \mathrm{U} / \mathrm{ml}$ & 6 & 2 & 3 \\
\hline Serum albumin $<3.6 \mathrm{~g} \%$ & 10 & 4 & 6 \\
\hline Serum y-globulins $>1.8 \mathrm{~g} \%$ & 9 & 4 & 4 \\
\hline \multicolumn{4}{|l|}{ Presence in the serum of Hepatitis } \\
\hline Associated Antigen & 3 & 2 & 3 \\
\hline \multirow{3}{*}{\multicolumn{4}{|c|}{$\begin{array}{l}\text { Immunological data: } \\
\text { Serum immunoglobulins: } \\
\text { Serum immunoglobulins: }\end{array}$}} \\
\hline & & & \\
\hline & & & \\
\hline IgG > $1600 \mathrm{mg} \%$ & 6 & 4 & 4 \\
\hline IgA $>400 \mathrm{mg} \%$ & 4 & 2 & 1 \\
\hline $\mathrm{IgM}>140 \mathrm{mg} \%$ & 7 & 4 & 3 \\
\hline \multicolumn{4}{|l|}{ Presence in the serum of: } \\
\hline $\begin{array}{l}\text { anti smooth muscle antibodies } \\
\text { anti glomerular basal membrane }\end{array}$ & 10 & 4 & 5 \\
\hline antibodies & 10 & 4 & 5 \\
\hline anti mitochondrial antibodies & 8 & 3 & 1 \\
\hline anti nuclear antibodies & $\mathbf{0}$ & 0 & 0 \\
\hline anti y-globulins antibodies & 6 & 1 & 4 \\
\hline
\end{tabular}

presence or not of jaundice, acne, spider naevi, the presence and the extent of hepatomegaly and splenomegaly, and the presence of vascular fragility.

Laboratory investigations performed were: serum bilirubin (Malloy and Evelyn, 1937), serum GO and GP transaminases (Wroblenski and Le Due, 1956), serum ornithine carbamyl transferase (OCT) (Ceriotti and Gazzaniga, 1966), serum total albumin and gamma globulins, BSP test, serum hepatitisassociated antigen (HAA) (Bedarida, Trinchieri and Carbonara, 1969; Shulman and Barker, 1969).

Immunological data considered were: serum 
immunoglobulins (IgG, IgA, IgM) (Mancini et al., 1965), serum antinuclear, anti-smooth muscle, antiglomerular basal membrane, anti-mitochondrial (Coons and Kaplan, 1950) and anti-gamma globulins antibodies.

All the patients had an oesophaged X-ray to look for varices, and an hepatic scintiscan. These radiological investigations were re-checked after 6 months in ten patients.

\section{Results \\ Clinical investigations}

In the three groups of patients there was a gradual decrease in the asthenia and dyspepsia, a decrease or disappearance of the arthromyalgias, a return to normal of bowel movements and diuresis. The improvement was greater in patients treated with Cy (group 1) than in those of the groups 2 and 3.

Patients treated with $\mathrm{Cy}$ showed swift regression or disappearance of the jaundice (if present) within the first month of treatment, while in the other two groups this decrease was slower or absent. Cutaneous findings of chronic hepatitis (acne, vasculo spiders) were emphasized in the first group with the passing of time, while in the other two groups there were no changes. Hepatomegaly, observed in all the patients before the beginning of the treatment, remained unchanged in nine subjects treated with $\mathrm{Cy}$ alone, whereas it decreased in the others. A remarkable reduction of the hepatomegaly and at the same time an increase of the splenomegaly was noticed in three patients, one of each group. The splenomegaly, if present, remained practically the same, except the three mentioned patients. Peripheral oedema, ascites, vascular fragility findings (when present) were reduced or disappeared in the first group of patients, while they remained unchanged or increased in the other two groups.

\section{Laboratory investigations}

Total serum bilirubin (Fig. 1), serum GO (Fig. 1) and GP transaminases, serum OCT receded permanently into the normal range within 2 months from the beginning of the Cy treatment. Periodic variations of these mean level findings in the other two groups were observed. Serum albumin and serum gamma globulins showed similar behaviour in the three groups of subjects. The mean levels of these findings had periodic variations. Variation of the serum HAA titre can be demonstrated in the HAA positive patients. Treatment with $\mathrm{Cy}$ increased the serum HAA titre in some cases.

\section{Immunological data}

Serum immunoglobulins G (Fig. 2), A,M levels and the frequency with which the serum antismooth muscle, anti-glomerular basal membrane, anti-gamma globulins antibodies may be found, showed periodic variations in the three groups of patients. Anti-mitochondrial antibodies disappeared from the blood within 12 months in the patients treated with Cy (Fig. 3). No patient showed serum antinuclear antibodies.

\section{Histological picture}

Table 1 shows the frequency of the type A and B (with or without cirrhosis) in the three groups of patients. Hepatic needle-biopsy was repeated after the first course of therapy in twelve subjects (eight of group 1, three of group 2, one of group 3). In all cases the histological picture showed no changes when compared with the initial conditions. The findings of piecemeal necrosis, degeneration, and hepatocellular necrosis were no worse. The marked fat degeneration of the liver cells observed in two subjects (one of group 1 and one of group 2) was considerably reduced.

\section{Radiological investigations}

Before the beginning of the treatment, oesophageal varices were present in one of the patients of group 1 , two of group 2 and one of group 3. In these four patients there was subsequent oesophageal bleeding. Oesophageal varices were not brought to light in the other subjects. Oesophageal X-rays were repeated in ten patients after 6 months, without alterations in the radiological picture.

Hepatic scintiscanning, performed in all the patients and re-checked after 6 months in ten cases, showed reduction of the size of the liver and simultaneous enlargement of the spleen in one patient of each group. In the other patients it remained unchanged.

\section{Statistical analysis}

Table 3 shows the statistical analysis of the results obtained in the three groups of patients. The same table explains the comparison of the results obtained with the Cy treatment with those obtained with $\mathrm{Cy}$ after cycles of corticosteroid therapy and after corticosteroids alone.

\section{Complications and mortality}

In two subjects treated with $\mathrm{Cy}$, who showed severe leucopoenia, the treatment was reduced or suspended. One patient of each group had oesophageal haemorrhage and consequently died. Portal-caval anastomosis was performed on a fourth patient (of group 2) and the recovery was satisfactory.

The other side-effects (hair loss in five patients, acne or herpes in four, arthrytis in one, scyatalgia in one) were reduced or disappeared after the end of the cycles of treatment. 


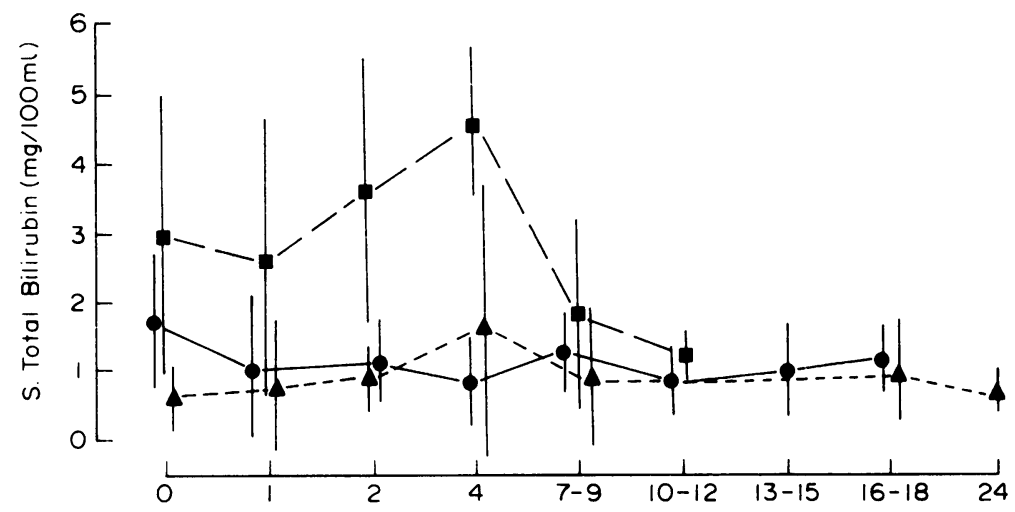

$\begin{array}{rrrrrrrrrr}\text { Cy: No. Studied } & 10 & 9 & 8 & 9 & 6 & 5 & 5 & 2 & \\ \text { St-Cy:No.Studied } & 4 & 4 & 4 & 4 & 3 & 2 & & & \\ \text { St:No. Studied } & 5 & 3 & 4 & 5 & 5 & & 4 & 4\end{array}$

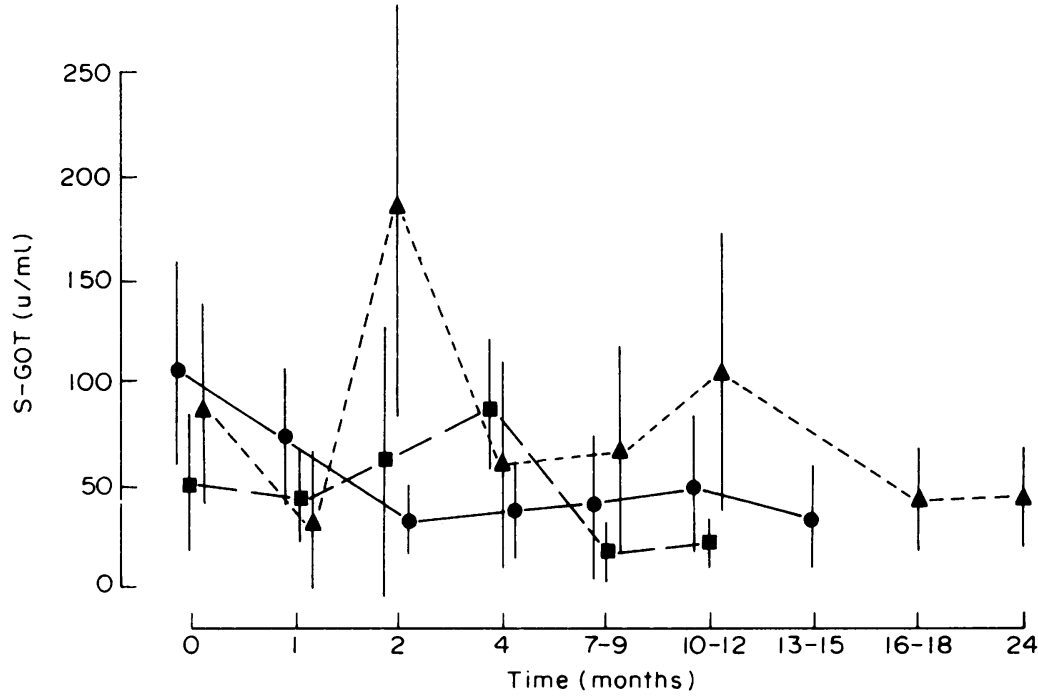

$\begin{array}{rrrrrrrrr}\text { Cy: No. Studied } & 10 & 10 & 8 & 8 & 6 & 5 & 5 & \\ \text { St-Cy:No. Studied } & 4 & 4 & 3 & 3 & 3 & 2 & & \\ \text { St:No. Studied } & 5 & 3 & 3 & 5 & 5 & 2 & 4 & 4\end{array}$

FIG. 1. Behaviour of serum total bilirubin and serum glutamic oxalacetic transaminase (S-GOT) in twenty patients with active chronic hepatitis treated with cyclophosphamide (Cy), with cyclophosphamide after steroid therapy (Cy after St), and with Steroids (St). , Cy; $-\longrightarrow$ St-Cy; $-\square--\triangle \mathrm{St}$.

\section{Current status of survivors}

Current status of survivors is summarized in Table 4.

\section{Discussion}

The results obtained in a group of patients with active chronic hepatitis treated with cyclophos- phamide were compared with those from two other groups of patients treated either with the same drug after cycles of corticosteroid therapy, or with corticosteroids alone.

The Cy treatment leads to a swift improvement in the clinical picture (subjective and objective findings). There is either no improvement or it is slower when 


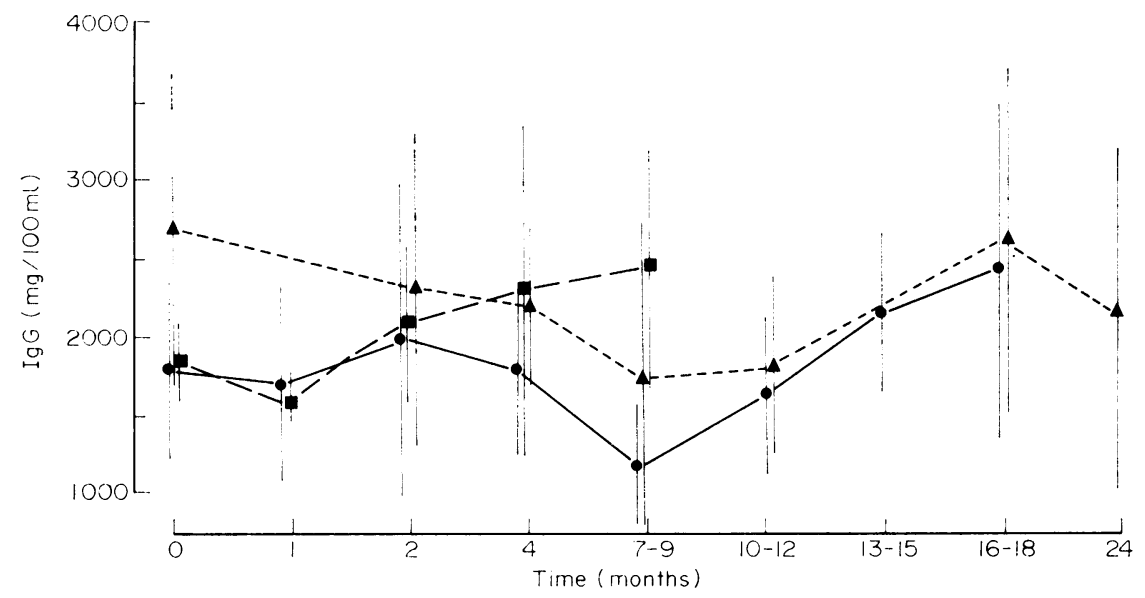

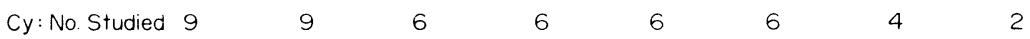

St-Cy: No. Studied $4 \quad 4 \quad 4 \quad 4 \quad 3 \quad 3$

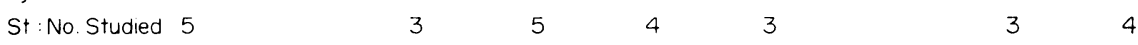

FIG. 2. Behaviour of IgG in twenty patients with ACH.

$\Delta-\ldots$ St.

$\mathrm{Cy} ; \mathrm{D}-\mathrm{C} \mathrm{St}-\mathrm{Cy}$;

Antimitochondrial antibodies

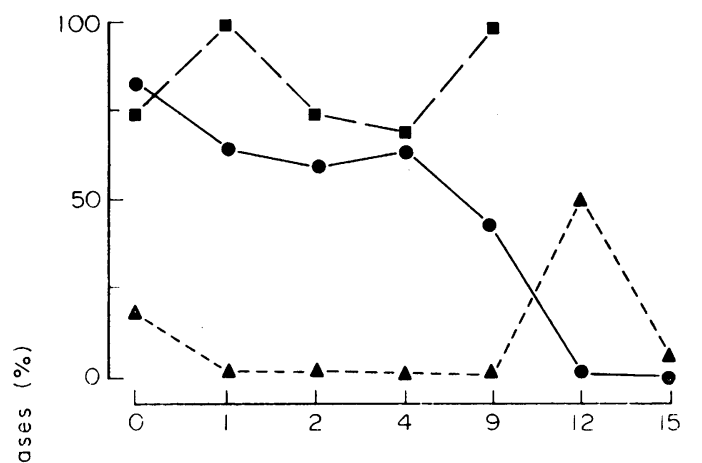

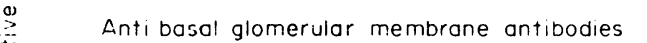

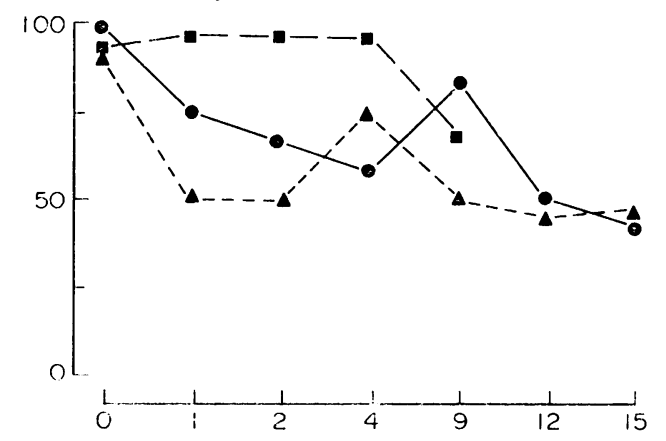

Anti smooth muscle antibodies

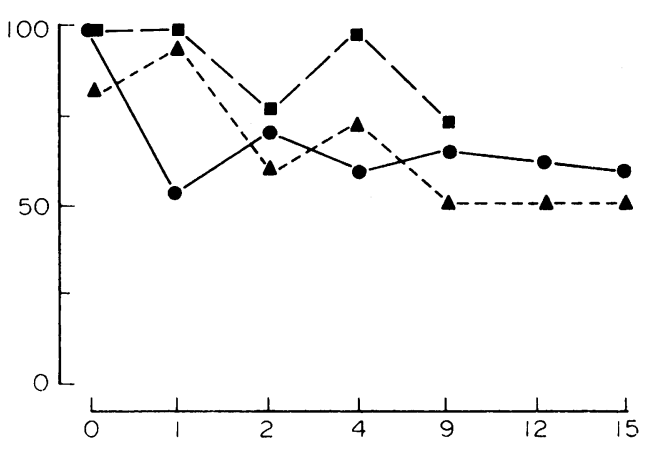

Anti gammaglobulins antibodies

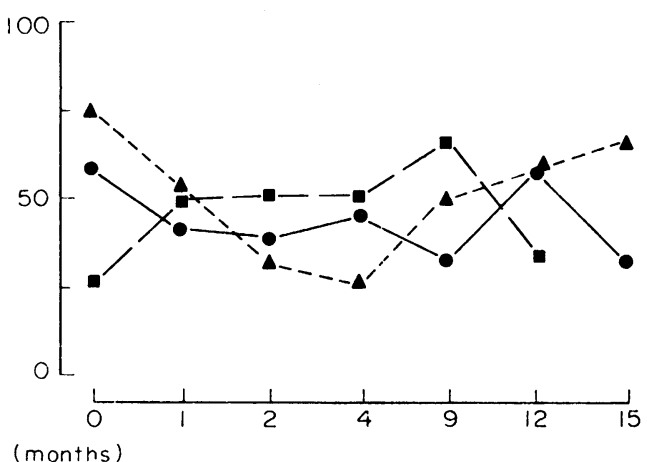

FIG. 3. Behaviour of some immunological findings in twenty patients with $\mathrm{ACH}$.

St-Cy; $\mathbf{\Delta}-\longrightarrow$ St. 
TABLE 3. Statistical analysis of the results concerning twenty patients treated with cyclophosphamide and/or with steroids after 1-24 months from the beginning of the therapy

\begin{tabular}{|c|c|c|c|c|c|c|c|c|c|c|}
\hline & \multicolumn{2}{|r|}{ Cy } & \multicolumn{2}{|c|}{ Cy after steroids } & \multicolumn{2}{|r|}{ Steroids } & \multicolumn{2}{|c|}{$\mathrm{Cy} / \mathrm{Cy}$ after steroids } & \multicolumn{2}{|c|}{ Cy/steroids } \\
\hline S. Total Bilirubin & & & & n.s. & & n.s. & after & $4 \mathrm{~m}(0.05)$ & & n.s. \\
\hline S.GOT & $\downarrow$ after & $\begin{array}{c}1 \mathrm{~m}(0.05) \\
2 \mathrm{~m}(0.005) \\
4 \mathrm{~m}(0.01) \\
9 \mathrm{~m}(0.02) \\
15 \mathrm{~m}(0.05)\end{array}$ & & n.s. & & n.s. & & n.s. & after & $2 \mathrm{~m}(0.01)$ \\
\hline S.GPT & $\downarrow$ after & $\begin{array}{r}2 \mathrm{~m}(0.01) \\
4 \mathrm{~m}(0.01) \\
15 \mathrm{~m}(0.05)\end{array}$ & $\downarrow$ after & $\begin{array}{l}4 \mathrm{~m}(0.01) \\
9 \mathrm{~m}(0.05)\end{array}$ & $\downarrow$ after & r $18 \mathrm{~m}(0.02)$ & & n.s. & after & $\begin{array}{l}2 \mathrm{~m}(0.01) \\
4 \mathrm{~m}(0.05)\end{array}$ \\
\hline$S . O C T$ & & n.s. & & n.s. & & n.s. & & n.s. & & n.s. \\
\hline S. Albumin & $\uparrow$ after & $12 \mathrm{~m}(0.02)$ & & n.s. & & n.s. & & n.s. & after & $12 \mathrm{~m}(0 \cdot 02)$ \\
\hline S. $y$-globulins & $\downarrow$ after & $\begin{array}{r}9 \mathrm{~m}(0.01) \\
12 \mathrm{~m}(0.05)\end{array}$ & & n.s. & $\downarrow$ after & $2 \mathrm{~m}(0.05)$ & after & $9 \mathrm{~m}(0.025)$ & & n.s. \\
\hline S.IgG & $\downarrow$ after & $9 \mathrm{~m}(0.05)$ & & n.s. & & n.s. & after & $9 \mathrm{~m}(0.025)$ & & n.s. \\
\hline$S . \operatorname{Ig} A$ & & n.s. & & n.s. & & n.s. & & n.s. & & n.s. \\
\hline S.IgM & & n.s. & & n.s. & & n.s. & & n.s. & & n.s. \\
\hline
\end{tabular}

n.s., not significant; significant differences $(P)$ are between parentheses; $\mathrm{m}$, months.

TABLE 4. Current status of patients with $\mathrm{ACH}$ treated with $\mathrm{Cy}$ and/or steroids after 12-24 months of observation

\begin{tabular}{|c|c|c|c|c|c|c|c|}
\hline & $\begin{array}{l}\text { No. of } \\
\text { patients } \\
\text { treated }\end{array}$ & $\begin{array}{l}\text { No. of } \\
\text { patients } \\
\text { alive }\end{array}$ & $\begin{array}{c}\text { Cause of death } \\
\text { in the deceased } \\
\text { patients }\end{array}$ & $\begin{array}{c}\text { General condition } \\
\text { of the patients } \\
\text { living }\end{array}$ & $\begin{array}{l}\text { Liver } \\
\text { serological } \\
\text { tests }\end{array}$ & $\begin{array}{c}\text { Immunological } \\
\text { data }\end{array}$ & $\begin{array}{l}\text { Histological } \\
\text { data }\end{array}$ \\
\hline Cy & 10 & 9 & $\begin{array}{l}\text { bleeding from } \\
\text { oesophageal } \\
\text { varices }\end{array}$ & $\begin{array}{l}\text { excellent: } 4 \text { subjects } \\
\text { good: } \quad 5 \text { subjects }\end{array}$ & $\begin{array}{l}\text { normal: } \\
6 \text { subjects } \\
\text { abnormal: } \\
3 \text { subjects }\end{array}$ & $\begin{array}{l}\text { normal: } \\
6 \text { subjects } \\
\text { abnormal: } \\
3 \text { subjects }\end{array}$ & $\begin{array}{l}\text { unchanged: } \\
8 \text { subjects }\end{array}$ \\
\hline Cy after St & 4 & 3 & $\begin{array}{l}\text { bleeding from } \\
\text { oesophageal } \\
\text { varices }\end{array}$ & $\begin{array}{ll}\text { excellent: } & 1 \text { subject } \\
\text { good: } & 1 \text { subject } \\
\text { bad: } & 1 \text { subject }\end{array}$ & $\begin{array}{l}\text { normal: } \\
1 \text { subject } \\
\text { abnormal: } \\
2 \text { subjects }\end{array}$ & $\begin{array}{l}\text { normal: } \\
1 \text { subject } \\
\text { abnormal: } \\
2 \text { subjects }\end{array}$ & $\begin{array}{r}\text { unchanged: } \\
3 \text { subjects }\end{array}$ \\
\hline St & 6 & 5 & $\begin{array}{l}\text { bleeding from } \\
\text { oesophageal } \\
\text { varices }\end{array}$ & $\begin{array}{l}\text { excellent: } 1 \text { subject } \\
\text { good: } 4 \text { subjects }\end{array}$ & $\begin{array}{l}\text { normal : } \\
3 \text { subjects } \\
\text { abnormal: } \\
2 \text { subjects }\end{array}$ & $\begin{array}{l}\text { normal: } \\
3 \text { subjects } \\
\text { abnormal: } \\
2 \text { subjects }\end{array}$ & $\begin{array}{l}\text { unchanged: } \\
1 \text { subject }\end{array}$ \\
\hline
\end{tabular}

the Cy therapy is applied after corticosteroid treatment or when steroid treatment alone is followed.

Several of the biochemical data (bilirubinaemia, serum GOT, GPT, OCT) often normalize permanently only after the first cycle of Cy treatment. They show periodic variations with alternate reduction and increase outside the normal levels with the other therapies undertaken.

Albuminaemia and gamma globulinaemia, and some immunological findings (serum immunoglobulins, serum anti-smooth muscle, antiglomerular basal membrane, anti-gamma globulins antibodies) in the three groups of patients show periodically variations during the progression of the disease. In all the patients treated with $\mathrm{Cy}$, the serum mitochondrial antibodies disappear from the blood.

The histological picture, re-checked in twelve cases after the first course of $\mathrm{Cy}$, did not show any significant change when compared with the conditions before the treatment.
OesophagealX-rays and hepaticscintiscans showed no significant changes when re-checked after 6 months from the beginning of the Cy therapy.

Three patients-one from each group-died from oesophageal bleeding. A fourth patient (of group 2) also affected by this complication, was successfully operated of porta-caval anastomosis. Marked leucopoenia was found in two patients treated with Cy. Other Cy side-effects (loss of hair, herpes, scyatalgia) were quickly reduced or disappeared completely during the period of interruipton of this therapy.

Statistical analysis showed the significant improvement of several biochemical findings with $\mathrm{Cy}$ treatment (re-entry within the normal range of serum GOT, GPT, OCT, increase of serum albumin and loss of gamma globulins levels). Any significant favourable effect in the behaviour of these findings was obtained with $\mathrm{Cy}$ after steroid treatment or with steroid therapy. Nevertheless the comparison 
between the $\mathrm{Cy}$ group and the other two groups of patients did not show remarkably significant differences.

These preliminary results concerning the effects of Cy treatment in ACH and the comparison of these results with those obtained with $\mathrm{Cy}$ after steroids and with steroid treatments, lead to the following considerations.

The dose of Cy used is not hepatotoxic. Therapy is not accompanied or followed by important side-effects.

Cy treatment leads to swift improvement of the general condition and permanent return to normal of several biochemical and immunological data, especially in those patients in which ACH was not in an advanced stage.

However, the majority of the immunological findings show, in spite of this treatment, periodical variations between the normal and the pathological levels. It is not clear if this fluctuation of the immunological findings could be explained on the basis of the discontinuity of the treatment. The disease has periodic variations depending on the degree of activity.

Cy treatment gives the best results in patients with $\mathrm{ACH}$ when the condition has moderate immunological and histological levels of activity of the disease. In these patients the histological picture is, in most cases, that of chronic aggressive hepatitis type A.

Generally the results are very poor when this treatment is undertaken in the $\mathrm{ACH}$ with serious immunological and histological activity findings (chronic aggressive hepatitis type B, mainly with cirrhosis), even after other therapies have been used.

The preliminary results may be confirmed by further studies.

Some questions remain unanswered.

There is in some patients a contrast between the swift improvement of the clinical and biochenical picture and the persistence-in spite of the immunosuppressant treatment-of abnormal findings of activity of the disease (increase of serum immunoglobulins, persistence in the blood of anti-smooth muscle, anti-glomerular basal membrane, antigamma globulins antibodies). The effect of the Cy therapy on the serum HAA is not clear as the first course of treatment increased the HAA titre in some cases.

The speed of the improvement in the general condition, the return of working capacity, the normalization of several biochemical features, the non-progressivity of the histological picture observed in the histologically type A aggressive form $\mathrm{ACH}$ patients treated with $\mathrm{Cy}$, are the bases on which we propose to undertake this therapy at this stage of the disease.

On the other hand, the results obtained with Cy treatment in the histologically type $B$ aggressive form $\mathrm{ACH}$ patients gives preference to other therapies-such as corticosteroid treatment-in this advanced stage of the disease. In the advanced stage of the disease, Cy probably gives poor results because it cannot be developed into its active form by the greatly damaged liver.

Further observations are necessary to estimate the long-term effects of cyclophosphamide treatment in active chronic hepatitis.

\section{References}

AlePa, F.P., Zvaifler, N.J. \& Sliwinski, A.J. (1970) Immunologic effects of cyclophosphamide treatment in rheumatoid arthritis. Arthritis and rheumatism, 13, 754.

Bedarida, G., Trinchieri, G. \& Carbonara, A. (1969) The detection of Australia antigen and anti-Au antibodies by a rapid procedure combining electrophoresis and immunoprecipitation. Hematologica, 54, 591.

Booth, L.J. \& ABLE, G.M. (1970) Immunosuprressive therapy in adults with proliferative glomerulonephritis. Lancet, ii, 1010.

Brock, N. \& Hohorst, H.S. (1963) Über die Aktivierung von Cyclophosphaniol in vivo und in vitro. Arznei Forschmillel, 13, 1021.

Ceriotti, G. \& Gazzaniga, A. (1966) A sensitive method for serum ornithine carbamyl transferase determination. Clinica Chimica Acta, 14, 57.

Cook, G.C., Mulligan, R. \& Sherlock, S. (1971) Controlled prospective trial of corticosteroid therapy in active chronic hepatitis. Quarterly Journal of Medicine, 40, 159.

CoONS, A.H. \& KAPLAN, M.H. (1950) Localization of antigen by means of fluorescent antibody. Journal of Experimental Medicine, 91, 1.

De Groote, J., Desmet, V., Gedigk, P., Karb, G., Popper, H., Poulsen, H., Scheuer, P., SChmid, M., Thaler, H., Vehlinger, E. \& Wegler, W. (1968) A classification of chronic hepatitis. Lancet, ii, 526.

FAIRLEY, K.F., BarRIE, J.U. \& Johnson, W. (1972) Sterility and testicularatrophy related to cyclophosphamide therapy. Lancet, i, 568.

Grushin, C.M., Fine, R.N., Heuser, E. \& Lieberman, E. (1970) Cyclophosphamide therapy of idiopathic nephrosis. California Medicine the Western Journal of Medicine, 113, 1 .

KravitT, E.L., Stein, J.H., Kirkendall, W.M. \& Clifton, J.A. (1967) Mercaptopurine hepatoxicity in a patient with chronic active hepatitis. Archives of Internal Medicine, $120,729$.

LaVIN, P. \& Koss, L.G. (1971) Effects of a single dose of cyclophosphamide on various, organs in the rat. IIIElectron microscopic study of the liver. American Journal of Pathology, 62, 159.

MaCKaY, I. R., TAFT, L.I. \& Cowling, D.C. (1956) Lupoid hepatitis. Lancet, ii, 1323.

MACKAY, I.R. \& WoOD, I.J. (1962) Lupoid hepatitis: a comparison of twenty-two cases with other types of chronic liver disease. Quarterly Journal of Medicine, 31, 485.

MacKay, I.R., Weiden, S. \& Unger, B. (1964) Treatment of active chronic hepatitis and lupoid hepatitis with 6-mercaptopurine and azathioprine. Lancet, i, 899.

MACKAY, I.R., WeIDEN, S. \& HASKer, I. (1965) Autoimmune hepatitis. Annals New York Academy of Sciences, 124, 767.

Malloy, H.T. \& EvelYN, K.A. (1937) The determination of bilirubin with the photoelectric colorimeter. Journal of Biological Chemistry, 119, 481. 
Mancini, G., Vaerman, J.P., Carbonara, A.O. \& HereMANS, J.F. (1965) Immunochemical quantitation of antigens by single radial immunodiffusion. Immunochemistry, 2, 235.

Mistilis, S.B. \& Blackburn, C.R.B. (1967) The treatment of active chronic hepatitis with 6-mercaptopurine and azathioprine. Australian Annals of Medicine, 16, 305.

Naccarato, R., Farini, R., Chiaramonte, M., \& Fagiolo, U. (1972) Possibile correlazione patogenetica tra epatite acuta virale HAA positiva ed epatite cronica attiva HAA positiva. Gazzetta Sanitaria, 43, 315.

Nakamura, R.M. \& Weigle, W.O. (1970) Suppression of thyroid lesions in rabbits by treatment with cyclophosphamide after the induction of thyroiditis. Clinical and Experimental Immunology, 7, 541.

Page, A.R., Condie, R.M. \& Good, R.A. (1964). Suppression of plasma cell hepatitis with 6-mercaptopurine. American Journal of Medicine, 36, 200.

Paterson, P.Y., Drobish, D.G. \& Biddick, A.S. (1971) Cyclophosphamide inhibition of experimental allergic thyroiditis and thyroid antibody production in rats. Journal of Immunology, 106, 570.
Popper, H., Paronetto, F. \& Schaffner, F. (1965) Immune processes in the pathogensis of liver disease. Annals New York Academy of Sciences, 124, 781.

Santos, G.W. (1967) Immunosuppressive drugs. I. Federation Proceedings, 26, 907.

Shulman, N.R. \& Barker, F.C. (1969) Virus-like antigen, antibody, and antigen-antibody complexes in hepatitis measured by complement fixation. Science, 165, 304.

Solway, R.D., Baggenstoin, A.H., Elveback, L.R., Schoenfield, L.J. \& Summerskill, W.M.J. (1970) Are azathioprine and prednisone effective in the early treatment of active liver disease? Gastroenterology, 58, 995.

Steinberg, A.D., Kaltreider, H.B., Stables, P.J., Goetzl, E.J., TAlal, N. \& DeCKER, J.L. (1971) Cyclophosphamide in lupus nephritis: a controlled trial. Annals of Internal Medicine, 75, 165.

Sutnick, A.I., London, W.T. \& Blumberg, B.E. (1971) Australia antigen: a genetic basis for chronic liver disease and hepatoma. Annals of Internal Medicine, 74, 442.

Wroblenski, F. \& Le Due, G.W. (1956) Serum piruvic transaminase in cardial and hepatic disease. Proceedings of the Society of Experimental Biologiy and Medicine, 91, 569. 